\title{
It all starts with the ECG: cardiac MRI in combination with electrophysiological study to stratify arrhythmic risk in a patient with non-ischemic cardiomyopathy and preserved LVEF
}

\author{
Stefan Ailoaei ${ }^{1,2,3}$, Carina-Gabriela Ureche ${ }^{1,2,3}$, Alex Bostan ${ }^{1,2}$, Laura Tapoi', Dan Ursu', Anatolie Cazacu4,
} Radu Sascau ${ }^{1,3}$, Cristian Statescu ${ }^{1,2,3}$, Mihaela Grecu ${ }^{1,2}$

\begin{abstract}
A 45-year-old male, hypertensive and obese presented with a 3-months history of short episodes of intermittent palpitations. Clinical examination was unremarkable; however, the electrocardiogram documented major right bundle branch block and the presence of fragmented QRS in all precordial leads. His echocardiography documented a dilated left ventricle, with mild systolic dysfunction and moderate biventricular reduction of the global longitudinal strain. On angiography, the epicardial coronary arteries were normal. A cardiac MRI revealed diffuse transmural fibrotic lesions with non-ischemic pattern of the ventricles, suggestive of chronic myocarditis. The electrophysiological study induced two ventricular tachycardia morphologies which were ablated and an ICD for sudden cardiac death primary prevention was implanted. Fortunately, at 6 months follow-up our patient had no ICD therapies and reported an alleviation of symptoms. Keywords: myocarditis, risk stratification, electrophysiology study, ICD, primary prevention.
\end{abstract}

Rezumat: Pacient în vârsta de 45 ani, obez, hipertensiv se prezintă pentru un istoric de 3 luni de episoade de palpitații cu ritm rapid, rare și izolate, făă crize susținute. Examenul clinic nu relevă particularități, însă electrocardiograma de repaus documentează prezența unui bloc major de ramură dreaptă și complexe QRS fragmentate în toate derivațiile precordiale. Ecocardiografic, ventriculul stâng este dilatat, cu funcție sistolică globală ușor diminuată și strain global longitudinal biventricular redus. Angiografia coronariană relevă artere coronare epicardice normale. Imagistica prin rezonanță magnetică cardiacă (IRMC) scoate la iveală leziuni fibrotice difuze transmurale cu dispoziție non-ischemică, sugestive pentru diagnosticul de miocardită cronică. Studiul electrofiziologic induce două morfologii de tahicardie ventriculară, care au fost ablate, iar ulterior a fost implantat un defibrilator cardiac (ICD) în prevenția primara a mortii subite cardiace. Rezultatul post-ablație a fost unul favorabil, întrucât la urmărirea de la 6 luni pacientul declară îmbunătățirea semnificativă a simptomatologiei, iar interogarea ICD nu a documentat nicio terapie.

Cuvinte-cheie: miocardită, stratificarea riscului, studiu electrofiziologic, $\mathrm{DCl}$, prevenția primară.

\section{PATIENT PRESENTATION}

A 44-year-old gentleman, a sales agent, known hypertensive, obese and dyslipidemic presented with a 3-months history of fatigue and palpitations of abrupt onset and termination, a duration of up to I minute, accompanied by dyspnea. His home medication included Candesartan $8 \mathrm{mg}$ OD and Atorvastatin $10 \mathrm{mg}$ OD. The physical examination was within normal limits, with a blood pressure of $130 / 80 \mathrm{mmHg}$, regular heart rate of $92 \mathrm{bpm}, \mathrm{SpO}_{2}$ of $100 \%$ on room air and

\footnotetext{
' Department of Cardiology, „Prof. Dr. George I. M. Georgescu” Institute of Cardiovascular Diseases, lasi, Romania

2 Department of Electrophysiology, „Prof. Dr. George I. M. Georgescu” Institute of Cardiovascular Diseases, EHRA Recognized Training Center, lasi, Romania

${ }^{3}$,Grigore T. Popa” University of Medicine and Pharmacy, lasi, Romania

${ }^{4}$ German Center of Diagnosis, Chisinau, Republic of Moldova
}

\section{Contact address:}

Stefan Ailoaiei, Department of Cardiology, ,Prof. Dr. George I. M. Georgescu” Institute of Cardiovascular Diseases, lasi, Romania.

E-mail: stefan.ailoaei@yahoo.com 
temperature of $37^{\circ} \mathrm{C}$. The patient was a non-smoker with no history of drug abuse, previous heart surgery, recent invasive procedures or dental intervention.

\section{INITIAL WORK UP}

Laboratory tests revealed elevated lipid profile (cholesterol $235 \mathrm{mg} / \mathrm{dl}$, LDL cholesterol $171 \mathrm{mg} / \mathrm{dl}$, triglycerides $180 \mathrm{mg} / \mathrm{dl}$ ), but otherwise normal complete blood count, inflammatory markers, liver, renal and thyroid function. In spite of the normal physical examination and blood tests, the electrocardiogram (ECG) showed sinus rhythm $90 \mathrm{bpm}, \mathrm{QRS}$ axis at 0 degrees and major right bundle branch block with notching in the nadir of the $S$ wave in all precordial leads. $A$ transthoracic echocardiogram (TTE) was performed and documented mildly dilated left ventricle (LV), with mild systolic dysfunction (ejection fraction (EF) of $45 \%$ ) and moderate reduction of the global longitudinal strain (GLS - I5\%), as well as a moderate reduction of the right ventricular (RV) GLS (-I4\%). On

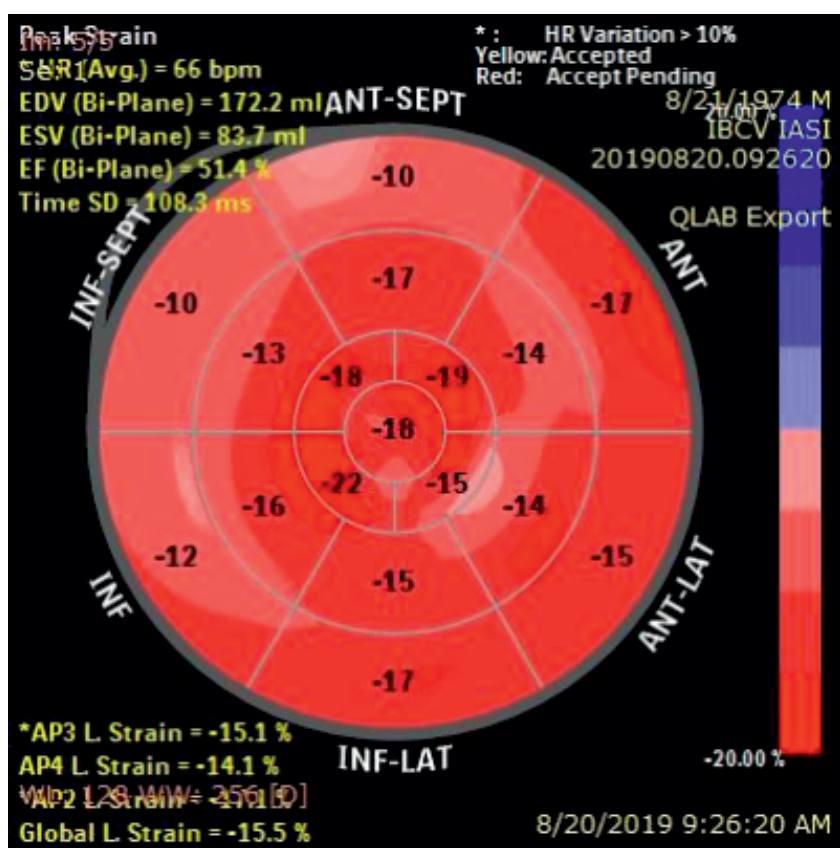

Figure 2. Longitudinal Strain Bull's eye: moderately reduced GLS (-15.5\%).

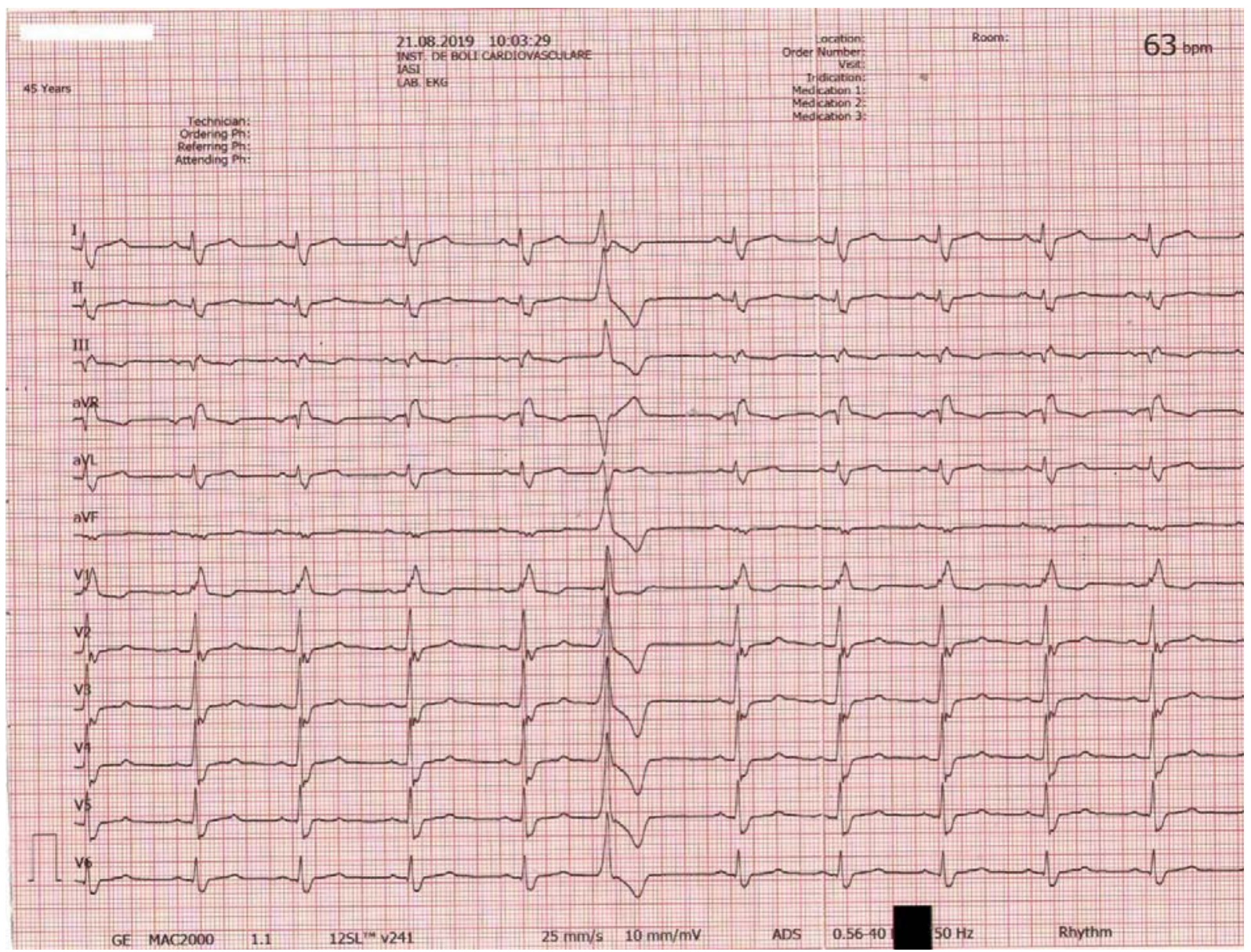

Figure I. ECG at presentation: Sinus rhythm 63/min, major right bundle branch block, QRS fragmentation in precordial leads. 
angiography, the epicardial coronary arteries presented no significant lesions. A Holter monitoring revealed no malignant ventricular arrhythmias, but frequent polymorphic ventricular premature beats (VPB) (4000 VPBs/24 hour).

\section{DIAGNOSIS AND MANAGEMENT}

In view of a high suspicion of a non-ischemic cardiomyopathy, the patient underwent a cardiac MRI'. Surprisingly, it revealed biventricular diffuse transmural fibrotic lesions with non-ischemic pattern, suggestive for post-myocarditis sequelae. In addition, it confirmed the moderate reduction in both the right and left ventricular global longitudinal strain shown on the echocardiography. Lesions transmurality together with reduced strain values and high number of viable myocardial channels within the scar (potential reentry circuits), suggested our patient was at high risk for sudden cardiac death (SCD) due to malignant ventricular arrhythmias, despite its preserved LVEF. In this regard, an electrophysiological (EP) study was performed, which induced two ventricular tachycardia

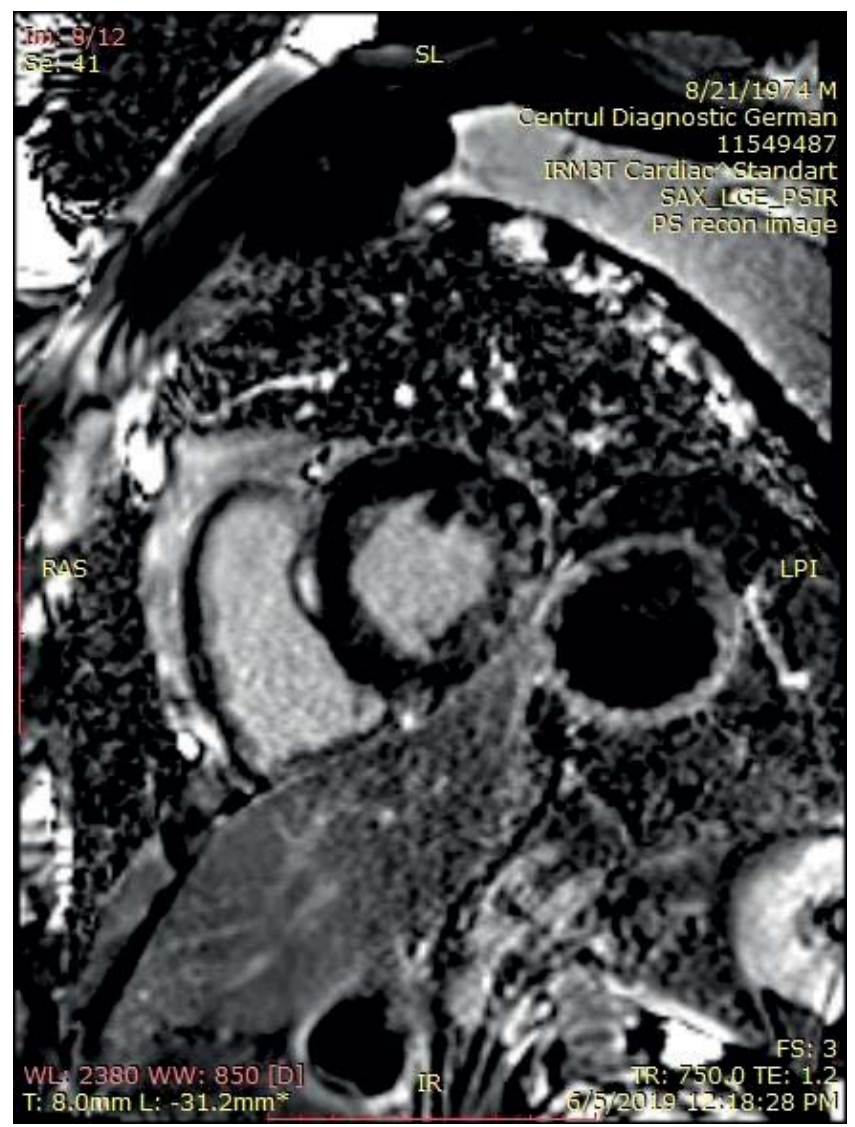

Figure 3. Late gadolinium enhancement short axis view: diffuse fibrosis on the LGE images.

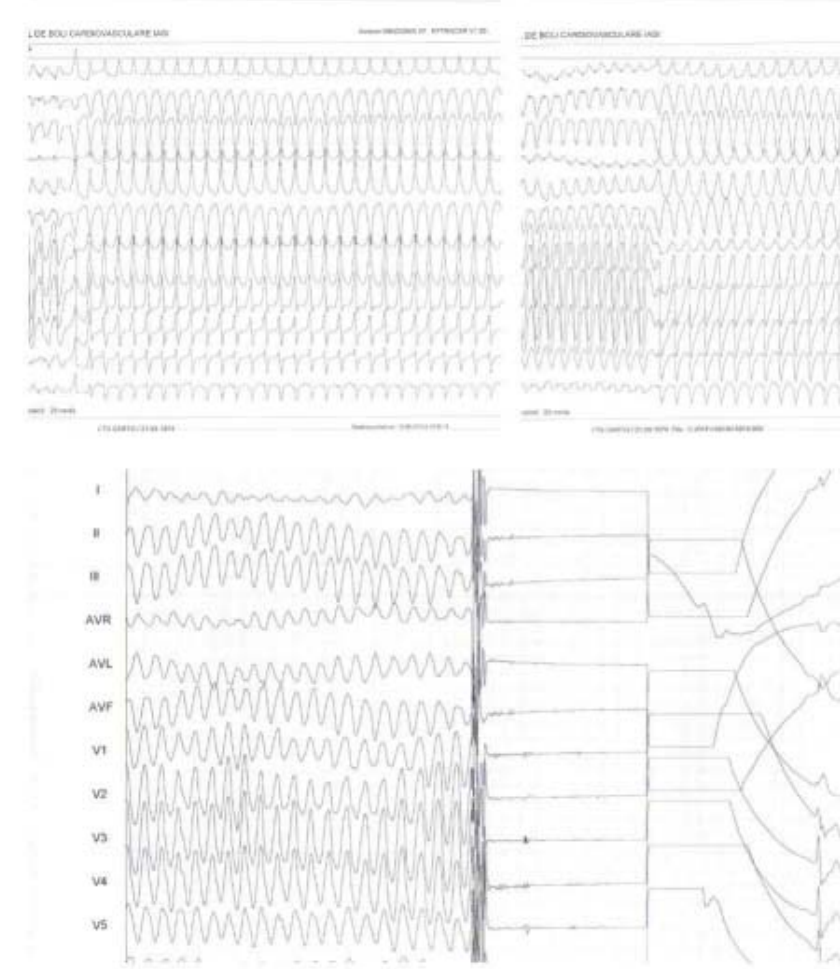

Figure 4. The two VT morphologies. Deterioration to VF.

morphologies, with hemodynamic compromise, requiring urgent electrical cardioversion. An endocardial radiofrequency ablation was performed, guided by arrhythmogenic substrate mapping, targeting abnormal potentials within the scar and at its borders. At the end of the procedure the induction protocol was negative for monomorphic ventricular tachycardia, but ventricular fibrillation was still inducible, so an ICD was implanted shortly after for the SCD primary prevention.

\section{FOLLOW-UP}

The patient was discharged under a small dose of Amiodarone (I00 mg OD) for 3 months post-ablation, given the inducibility of ventricular fibrillation at the end of the electrophysiological study and high myocardial excitability, and received the standard treatment for chronic heart failure (Carvedilol $6.25 \mathrm{mg}$ BID, Eplerenone $50 \mathrm{mg}$ OD, Candesartan $8 \mathrm{mg}$ OD) and dyslipidemia (Atorvastatin $10 \mathrm{mg} O D$ ), reporting an alleviation of the palpitations. The 6 and 12 months ICD followup showed no sustained ventricular arrhythmias. A repeat ECG and Holter was performed documenting ventricular extrasystole with origins from both RV and $L V$, but with a reduction in the number of VPBs (I500 

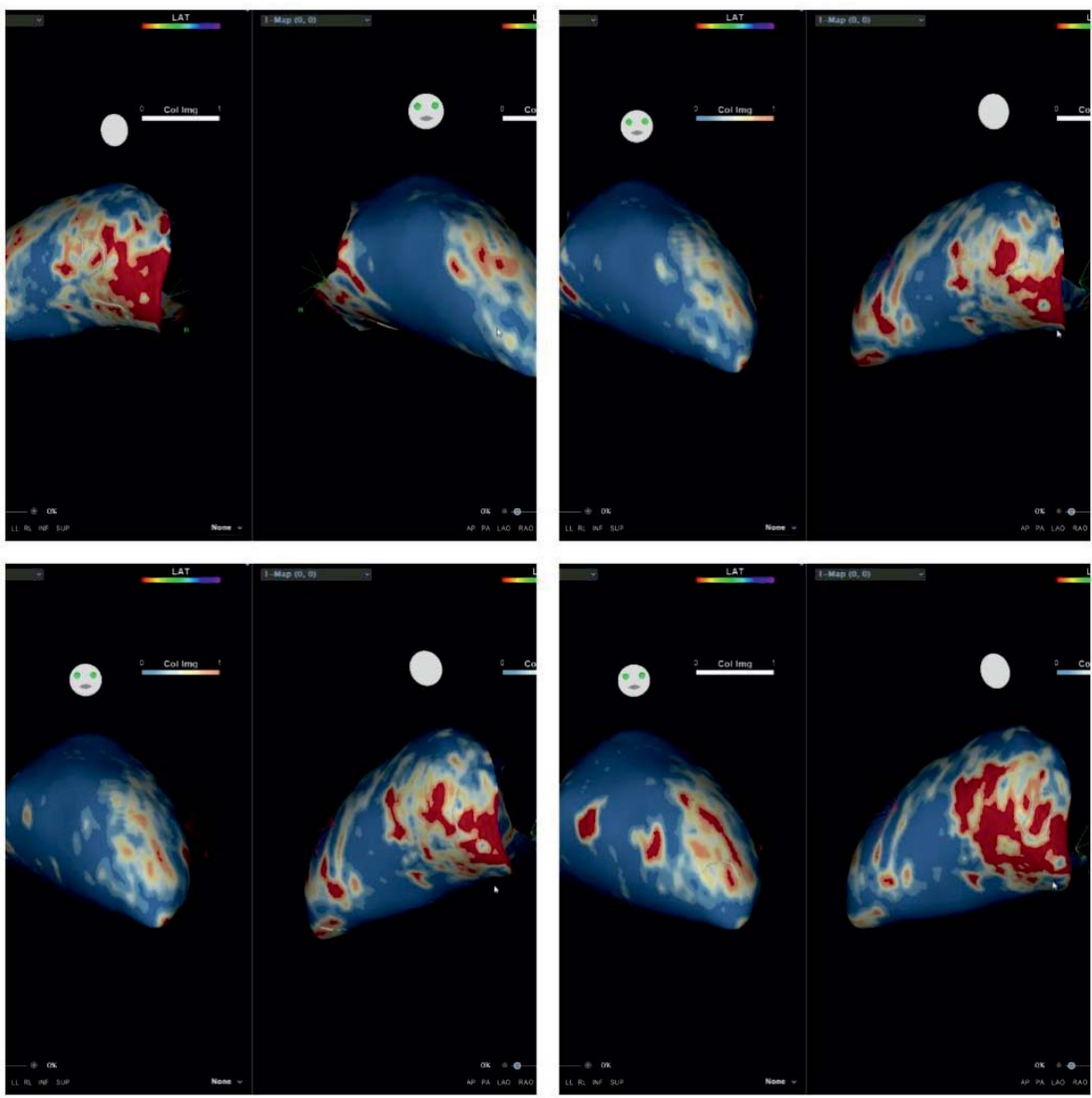

Figure 5. 3D fibrosis, ADAS software images imported into CARTO; red colour = scar; blue color = normal myocardium.

VPBs/24 hours). Despite the apparent improvement of the symptoms, a repeat TTE was performed showing a further decrease in the GLS of the LV (-10\%), suggesting the progression of the disease and the patient was further referred for extensive investigations (genetic, immunologic). A repeat CMR would have been helpful in this case, to reveal whether there is persistent disease activity despite normal cardiac enzymes and inflammatory markers. In this regard, it is especially helpful in identifying high-risk patients and has prognostic value. Unfortunately, our patient has not had further CMR evaluation until this point in time.

\section{CONCLUSIONS}

This case underlines the importance of recognizing the presence of fragmented QRS on the 12-lead ECG in apparently healthy subjects, as an indicator of myocar- dial scarring and a high risk of adverse cardiac events ${ }^{2}$. Furthermore, speckle-tracking imaging in cardiomyopathies may serve as a non-invasive tool during follow up, potentially revealing substrate progression. SCD risk stratification in non-schemic cardiomyopathies patients with preserved ejection fraction remains a challenge. In this regard, the presence of negative prognostic factors on cardiac MRI such as a reduction in the strain values, the presence of arrhythmogenic substrate (scar size, transmurality, intra-scar viable myocardial channels), in combination with a positive EP study (induction of sustained monomorphic ventricular tachycardia or ventricular fibrillation) could identify SCD high risk patients that could benefit from ICD in primary prevention, despite preserved LVEF ${ }^{1,3}$.

Conflict of interest: none declared. 


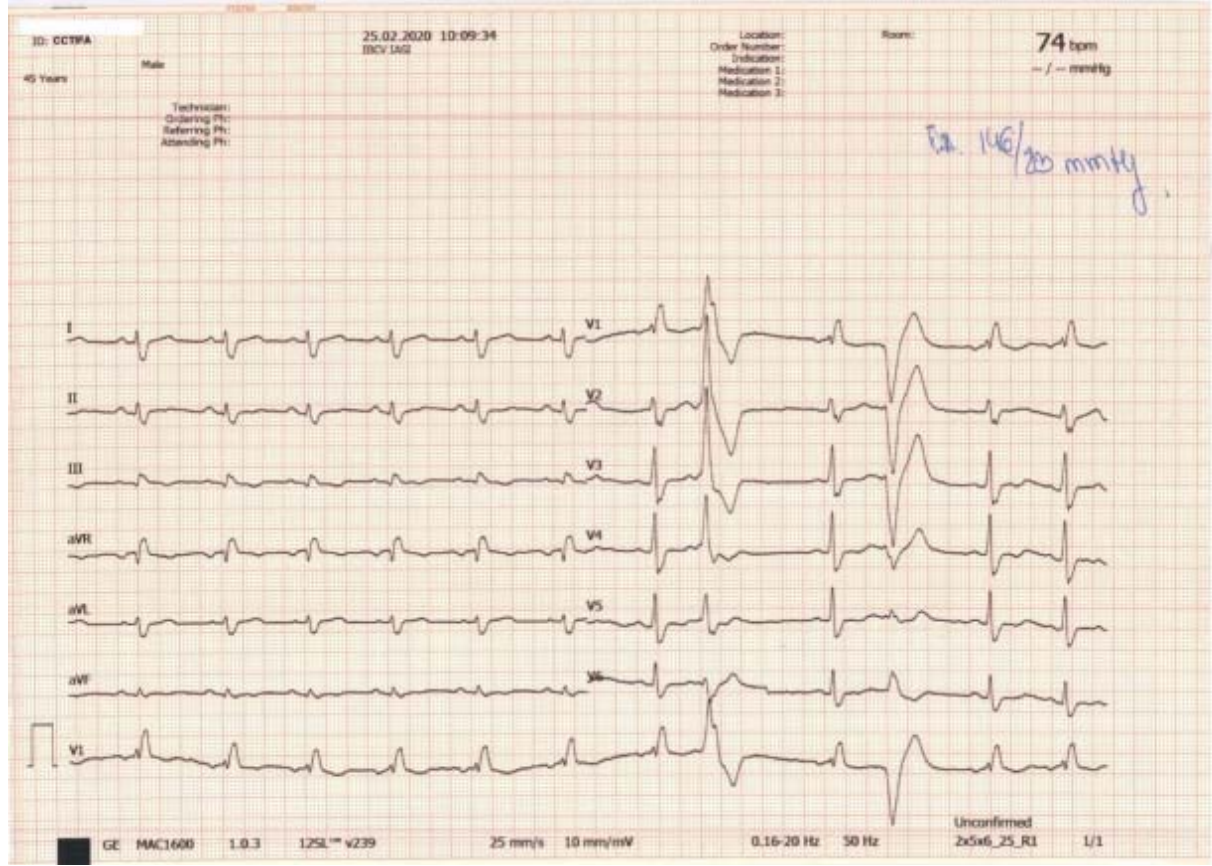

Figure 6. Follow up ECG.VPBs originating from both ventricles.

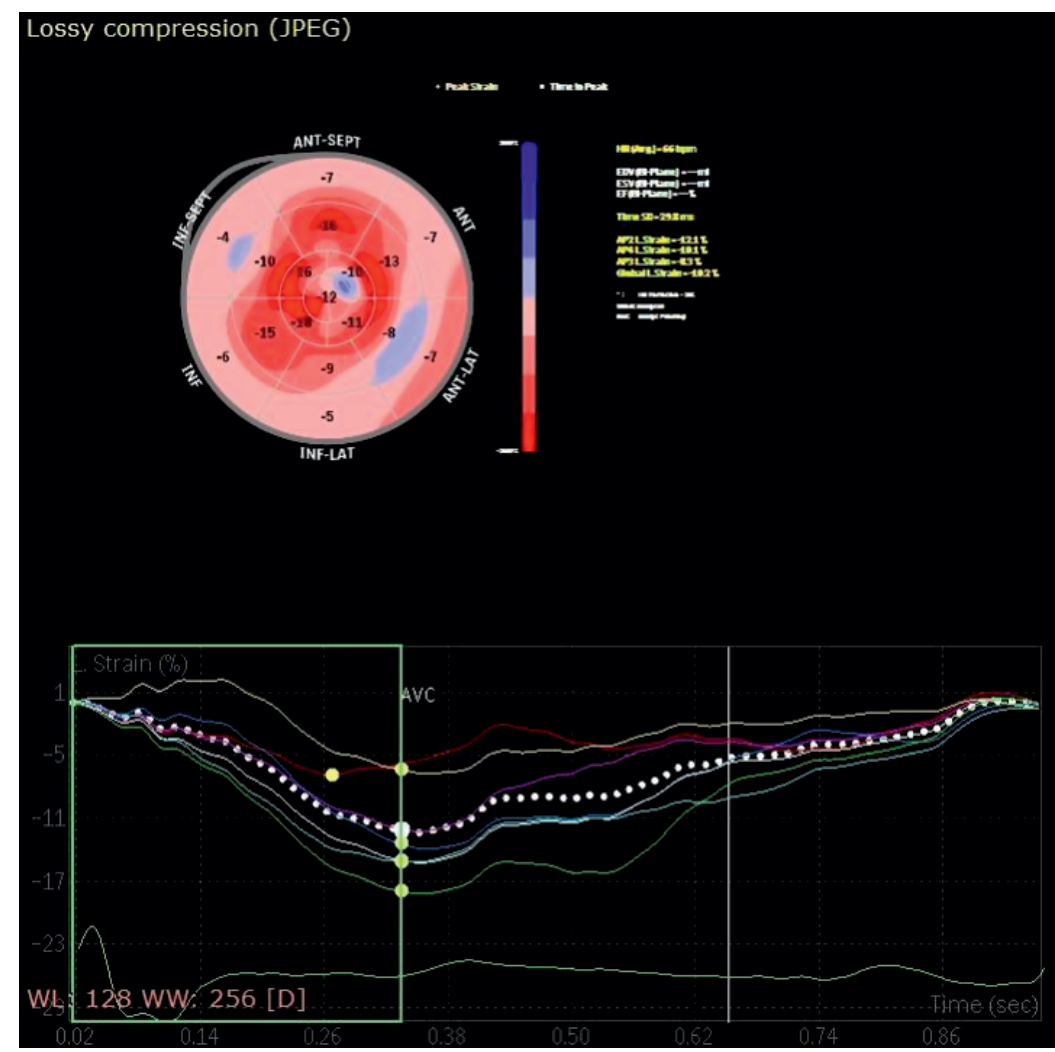

Figure 7. Follow up strain showing progression of the disease.

\section{References}

I. Gatzoulis Konstantinos A. et al. Primary Prevention of Sudden Cardiac Death in a Nonischemic Dilated Cardiomyopathy Population. Circ. Arrhythm. Electrophysiol. 6, 504-5 I2 (2013).
2. Akhtar, M. \& Elliott, P. M. Risk Stratification for Sudden Cardiac Death in Non-Ischaemic Dilated Cardiomyopathy. Curr. Cardiol. Rep. 2I, I55 (2019).

3. Ghannam, M. et al. Risk stratification in patients with nonischemic cardiomyopathy and ventricular arrhythmias based on quantification of intramural delayed enhancement on cardiac magnetic resonance imaging. J. Cardiovasc. Electrophysiol. 3I, I762-1769 (2020). 